\title{
Passive and Antipassive in Tugen
}

\author{
Prisca Jerono \\ University of Nairobi \\ Kenya
}

\subsection{Introduction}

The passive and the antipassive are constructions that affect the argument structure of the verb. The two operations are taken to be similar with respect to their detransitivizing nature. In the passive, the subject is demoted and the object promoted while in the antipassive the object is demoted. These constructions are formally marked. Tugen, a southern Nilotic language of Kenya is taken to have both constructions. There has been debate concerning the true nature of the passive in some languages. Some languages are taken to have a true (canonical) passive, while others are taken to have some form of the true passive. This paper attempts to relook at the nature of this passive construction in Tugen. There has also been debate regarding the relationship of the antipassive with other constructions such as ergatives and unaccusatives. This paper also attempts to find out if there is any relationship between the Tugen antipassive and these constructions. It also shows how these two constructions behave with respect to verb valence as well as their functions.

The discussion of the nature of the passive and the antipassive construction is being undertaken against the background of the minimalist framework where verbs enter numeration already inflected with phi features. The sentence structure contains various heads depending on the features within the VP and case is arrived at by checking and pairing off features either overtly before spell out and covertly at LF. Case for the various arguments is assigned by the features of the verb. The case features of the various arguments are checked at their relevant specifier-head configurations., (Chomsky 1995, Jerono 2012, Schröder 2008). In this discussion, the antipassive verb in Tugen is taken to lack structural case to value the internal argument, and, therefore does not bear EPP features. This forces the object to be interpreted in the VP at LF (Alridge 2012). The passive on the other hand blocks agreement features from assigning nominative case to the external argument. In the passive the verb does not have agreement features therefore, does not also contain EPP features. The subject is therefore interpreted also in the VP at LF. In the sentence structure therefore, passive and antipassive heads are created to check for these detransitivizing features.

\subsection{Passive in Tugen}

Discussions on the passive construction in languages have shown that it appears as canonical in some languages, while in others it is non-canonical. The canonical passive construction is defined according to the characteristics given by Dixon \& Aikhenvald (2000:7):

(i) it applies to an underlying transitive and derives an intransitive

(ii) the underlying $\mathrm{O}$ becomes $\mathrm{S}$

(iii) underlying A goes into peripheral function being marked by a noncore case, adposition etc. The argument can be omitted, but there is always the option of including it

(iv) there is some formal explicit general marking either by a verbal affix or a periphrastic verbal construction.

Non-canonical passives on the other hand are constructions in a number of European languages that have passive- like interpretations but do not seem to share all the properties with their canonical counterpart (Alexiadou \&Schafer, 2013).

Most definitions of the passive focus on syntactic and morphological manifestations while a few incorporate the phonological aspects. The passive construction in Tugen is one that incorporates phonological aspects in its definition. It seems to be canonical in the sense that most of the characteristics enumerated by Aikhenvald \& Dixon (2000) above, seem to hold true for the Tugen passive as can be seen from the example:
1 (a)Tíl-èì
láàkw-éét
táápt-èè
Cut-IMP child-sg
flower-sg 
The child is cutting a flower

(b) Kí-tíl-è̀ tánt-è̀

PASS-cut-IMP flower-sg

The flower is being cut

$\begin{array}{cl}\text { (c) *Ki-til-ei } \quad \text { taapt-ee } & \text { laakw-ee } \\ \text { PASS-cut-IMP flower-sg child-sg } \\ \text { The flower is being cut by the child }\end{array}$

In the example the transitive in 1(a) appears as intransitive in 1(b). Passivization is brought about by the verbal prefix $-k i$-. The agent as seen in 1(b) is omitted and there is no option of including it as seen in 1(c). Tugen has a VSO/VOS word order; the order of the arguments is relatively free. Case is marked through the use of tone. The case system of the Tugen is the marked nominative (Jerono 2012). Arguments bear absolutive case marking in citation but acquire different tonal patterns to show the nominative case as seen in:

2 (a) Pír-èì sè̀̀-éé pùsí-1́
beat-IMP dog-sg cat-sg
The dog is beating the cat
2 (b) Pír-èì púsí-1́ séès-èè
beat-IMP cat-sg dog-sg
The cat is beating the dog.

In (2a) the sentence structure is VSO with the subject seesee 'dog' having HLH tone while the object pusii 'cat' has the absolutive LH tone. In 2(b) the sentence structure is also VSO with the subject pusii having a nominative $\mathrm{H}$ tone while the object seesee has an accusative HL tone. In citation form, all the nouns bear the absolutive tone patterns. The tone patterns change only in the nominative. Due to the use of tone in case distinctions, the word order of the NPs is relatively free. However a SVO pattern is used only for focused/topicalised constructions which are indicated by the particle $n e / c h e / k o^{* 1}$ after the NP as seen below:

$\begin{array}{lll}\text { 3(a)Lààkw-éé né ám-éí } & \text { lògò-yáá } \\ \text { child-sg that eat-IMP } & \text { fruit-sg } \\ \text { The child that is eating a fruit } & \\ \text { (b)Lààg-ók ché ám-éí } & \text { lògò-ék } \\ \text { child-pl that eat-IMP } & \text { fruit-pl } \\ \text { The children that are eating fruits } & \\ \text { 3(c)Kàrì-ì kó kà-rús } & \text { kó-ót } \\ \text { car-sg } & \text { is pst-crash } & \text { house-sg }\end{array}$

It is the car that crashed the house.

In the focused/topicalised constructions the NP bears absolutive case.

In passive constructions, the subject is taken to originate in the post verbal position in the D-structure, Chomsky (1981:53-55). The subject then moves to the preverbal position and leaves a trace to avoid violating the case filter. Baker (1988) says that the passive morpheme is an argument of the verb. Therefore, the addition of the passive morphology entails the addition of a verb's internal arguments. This internal argument must receive an external $\Theta$ role inherently assigned by the verb. The subject position is deprived of the external $\theta$-role and so it becomes free and therefore a possible landing site for NP movement. In Tugen, NP movement does not seem to occur. The passive morpheme does not seem to add any internal argument to the verb. The subject position is not taken by the object because it remains in situ as can be seen from the tonal patterns which do not change in the active and passive. In ergative languages, the $\mathrm{S}$ of the intransitive bears the same case marking as the $\mathrm{O}$ of the transitive clause, (Schroder 2015). Tugen therefore shows an ergative strategy in making passive as in the example below:
3.(a)Kà-sír chéép-tó káíné-nyì pst-write F-girl name-POSS
The girl wrote her name
(3(b)Kà-kí-sír káíné-nyì pst-PASS-write name-POSS Her name was written.

\footnotetext{
${ }^{1}$ ne for singular; che for plural and ko for contrastive focus 
In sentences, agreement markers do not appear for the third person either in the singular or plural. Agreement markers only appear for the $1^{\text {st }}$ and $2^{\text {nd }}$ person. When these agreement markers are present, the lexical NPs are omitted except in cases where emphasis is required as shown in 4(a) otherwise the sentence appears as in 4(b). The passive morpheme in Tugen can also be used in verbal construction with pronominal arguments as show in 4(c).

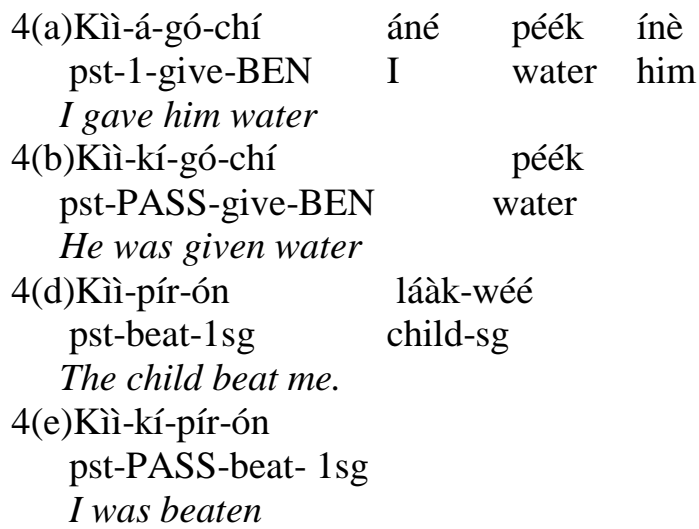

From the examples above we can see the pronominal objective marker is retained in 4(c) and 4(e).This goes to show that the construction has an implicit subject because the object is not promoted. It remains in its position with the absolutive case. This is clear also from the 4(e) which has a pronominal object. The passive morpheme here replaces the agreement morpheme. The passive morpheme in the case of Tugen does not add any argument. Instead, the passive affix blocks the appearance of the subject syntactically in line with its valence reducing properties by removing the agreement features from the verb. The subject, however, is logically present, with its features being largely human, unspecific and plural. In this regard, sentence structure has a passive head in order to check for this passive feature. The interpretation of the subject is done at LF.

\subsection{Passive and Impersonal constructions}

On examination of the passive morpheme in Tugen, we find that the use of morpheme $\{\mathrm{ki}\}$ results in an interpretation of an agent that involves an indefinite human collective (Jerono 2014).This is what Sierwieska (2010) calls the third person plural impersonal subject, (3pl IMPs) which is non-referential. She goes on to say that the 3pl IMPs excludes the speaker and the addressee and is widely used as a translation of the passive of European languages which do not have a passive. In this regard, Tugen does not have a "true" passive in the sense that this passive morpheme expresses this 3pl IMP subject. This morpheme also has no relation with the third person pronominal marker in Tugen; the third person pronominal in Tugen is null. However it resembles the $1 \mathrm{pl}$ marker morphologically but is differentiated functionally by the use of tone as seen below:

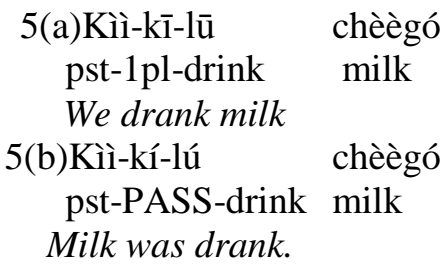

In 5(a) the 1Pl bears a Mid tone which spreads to the verb while in 5(b) the passive morpheme has a $\mathrm{H}$ tone that spreads to the verb. There has been debate concerning the relationship between the passive and impersonal constructions. Blevins (2003) argues that, there has been a misclassification of passive constructions in relation to impersonals. He attempts to distinguish the two constructions by saying that "whereas passivization detransitivizes a verb by deleting its logical subject, impersonalization preserves transitivity, and merely inhibits the syntactic realization of a surface subject", (p.475). He acknowledges that in intransitive constructions, deleting and suppressing a logical subject is not clear because the construction remains subjectless. This position seems to hold for Tugen. The passive construction in Tugen remains subjectless because the object of the transitive is retained. In order to distinguish the passive from the impersonal Blevins (ibid) says that the suppressed subject of an impersonal construction can sometimes serve as an antecedent for a reflexive pronoun whereas the subject of a 
passive never can. As regards this distinction in Tugen, we find that the suppressed subject can act as an antecedent of a reflexive pronoun as seen in:

6(a)Kì̀-ám ágé lògò-yáá ák fruit-sg and kó-sáás-kéí
pst-eat INF-hate-REF
Another ate a fruit and hated himself
6(b)Kì-kí-ám lògò-yáá ák ké-sáás-kéí
pst-PASS-eat fruit-sg and ' and hated themselves.
The fruit was eaten and 'they' hate-REF

In 6(a) the reflexive pronoun kei has age 'another' as its antecedent. In 6(b) the passive the subject is suppressed and the reflexive pronoun kei has this suppressed as an antecedent as evidenced by the infinitival marker kee which appears in the plural unlike in 6(a) which appears in the singular just like the pronominal singular subject age. This implies that the Tugen construction is not a true passive construction but does fit within the classification of the passive prototype according to Shibatani (1985) where the agent is a component of the semantic valence. In the impersonal construction in Tugen, the affix $k i$ - on the verb blocks the appearance of the syntactic argument. The subject therefore appears as null syntactically. However, feature checking is done covertly for this argument at LF.

\subsection{Passive and Unaccusatives}

The passive can apply both to transitive and intransitive constructions. The suppression or deletion of arguments has been associated with unaccusatives and unergative verbs. Blevins (2003) says that passivization targets logical subjects and prevents it from applying to unaccusative verbs which have no implicit subject. In Tugen, unaccusatives are differentiated lexically from other verbs and do not to permit passivization as seen in 7(d) below:

7(a) Kì̀-péél chítò
pst-burn kó-ót
The person burnt the house
7(b) Kì̀-kí-péél house-sg
pst-PASS-burn kó-ót
The house was burnt.
7(c)Kì̀-lál kouse
pst- burn house-sg
The house burned. kó-ót
7(d)*Kì-kí-lál house-sg
pst-PASS-burn house
The house was burnt.

In 7(a) the transitive sentence shows the subject chito 'person' is the agent of the action. In 7(b) the construction is impersonal in the sense that the agent is unknown/unspecified. In 7(c) the construction is ergative; it occurs on its own. In the case of an ergative construction, the case of the sole argument has nominative case pattern. Other unaccusatives in Tugen bear an additional $\{a k\}$ suffix to show this status as in:
8(a) Kà-yáát kúrg-éé láàk-wéé pst-open door-sg child-sg The child opened the door

8(b) Kà-yáát-àk kùrg-éé
pst-open-self door-sg
The door opened by itself

The unaccusatives that have this extra suffix cannot be passivized.

\subsection{Passive and Valency}

The impersonal construction (passive) in Tugen participates in operations that affect the valence of the verb, Marantz (1984). Such operations include reciprocals and applicatives. The reciprocal operation reduces the valence of the verb. In Tugen, the reflexive and the reciprocal are marked by kei on the verb. However the passive cannot be used together with the reflexive. Abraham (2006:26) says that proper anaphoric reflexives disallow 192 
passivization, because they fail to satisfy semantic transferability from the agent to the bearer of the thematic object. The use of the reciprocal in the passive is as shown below:

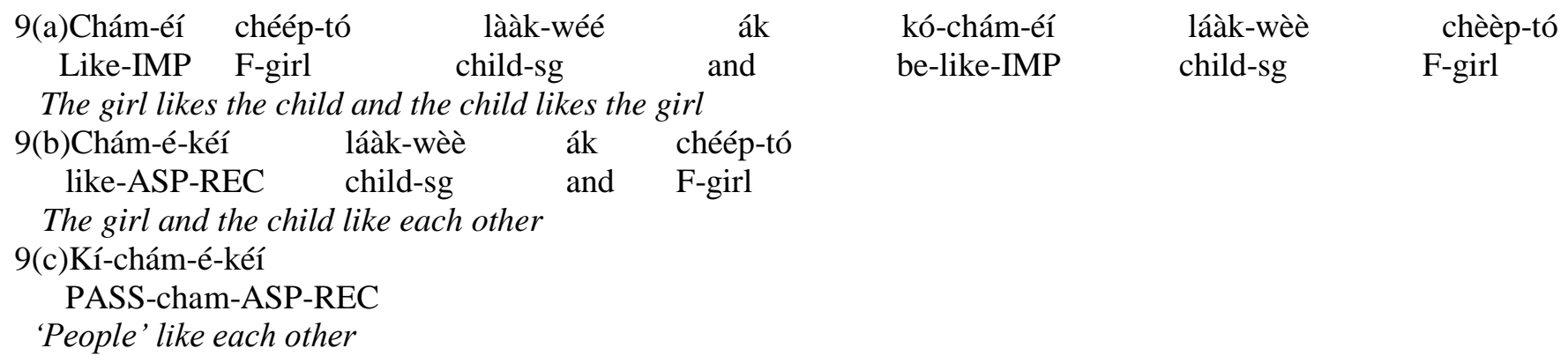

When the passive occurs with the reciprocal the sentence remains argumentless syntactically but logically there is an implicit argument. The passive can also co-occur with applicatives. The applicatives are valence increasing operations. The applicatives include the benefactive, the instrumental and the locative. The benefactive affix in Tugen is $\{$ chi $\}$. This affix is used to introduce the benefactive object. Its use makes the sentence to be ditransitive as seen in 10(a).The use of the benefactive and the passive reduces the valence of the verb by one argument as seen in 10(b):

$$
\begin{array}{cccc}
\text { 10(a)Kì̀-sóóm-chí } & \text { chéép-tó } & \text { pèèk } & \text { chèè-ròp } \\
\text { pst-borrow-BEN } & \text { F-girl } & \text { water } & \text { F-Mary } \\
\text { The girl asked for } & \text { water for Mary } & & \\
\text { 10(b)Kì̀-kí-sóóm-chí } & \text { chèè-ròp } & \text { péék. } \\
\text { pst-PASS-borrow-BEN } & \text { F-Mary } & \text { water } \\
\text { Water was asked for Mary ('People' asked for water for Mary) }
\end{array}
$$

The instrumental and the locative also introduce additional arguments which are also reduced by the use of the passive as seen in 11 and 12 below. The affix for both the instrumental and the locative is $\{-\mathrm{en}\}$ :

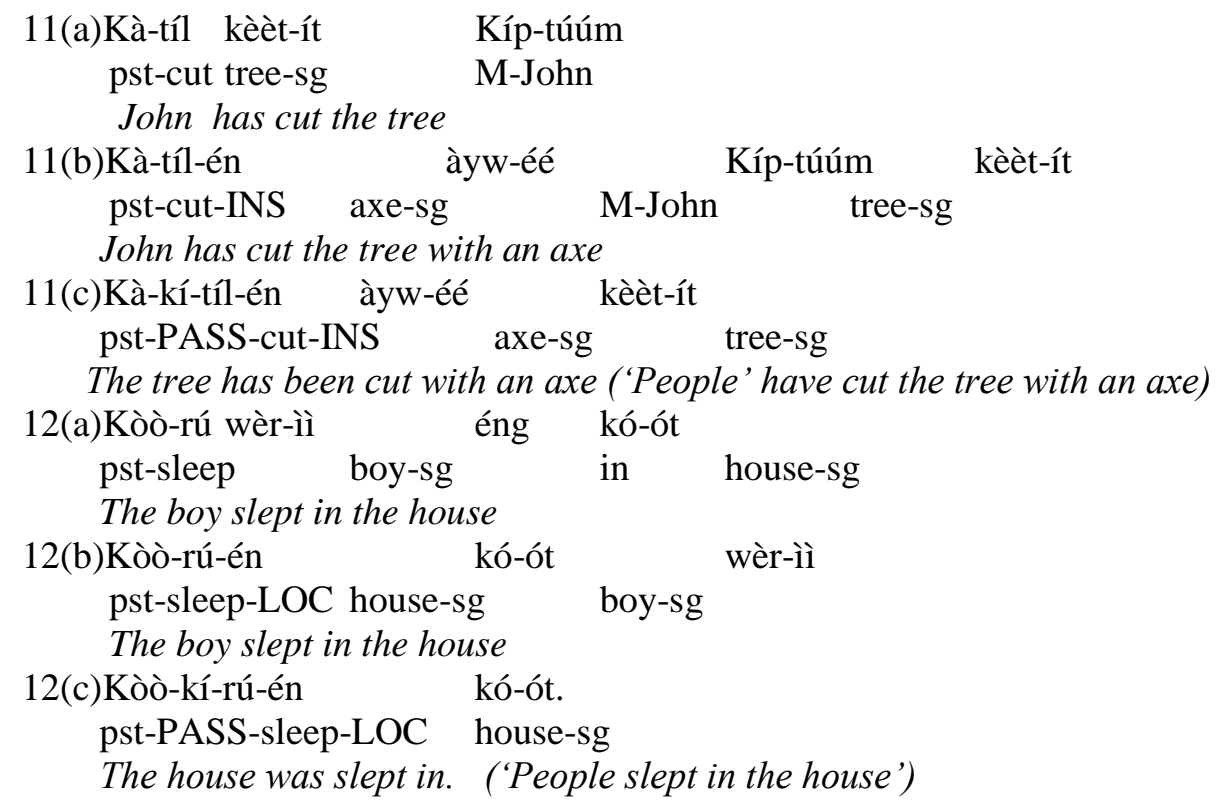

The construction in 11(b) has the suffix -en which introduces the instrumental aywee 'axe'. The use of the passive in 11(c) reduces one argument by omitting the agent. In 12(a), the locative is shown by the PP 'eng koot' 'in the house'. The use of the locative suffix in 12(b) increases the valence of the verb by introducing the locative argument to the verb phrase. The use of the passive in 12(c) removes the agent and thereby reduces the number of the arguments in the verb phrase. In terms of disambiguating the arguments, we can see that tone alone does not 
suffice because they all bear absolutive tone patterns. In such a situation, the language resorts to the animacy index as well as the semantics of the verb for disambiguation. Tugen therefore uses tone, animacy and semantics to assign case to its arguments.

\subsection{Antipassive}

According to Polinsky (2013), antipassives are constructions in which the logical object of a transitive (two place) predicate is not realized as a direct object. Instead, it appears as a noncore argument or left unexpressed (but presupposed). The antipassive is similar to the passive construction. The difference is that the arguments are demoted or unexpressed: in the passive it is the subject and in the antipassive it is the object. In both constructions, the sentence is syntactically intransitive though semantically transitive. Tugen has an antipassive construction. In Tugen the direct object (patient) is left implicit. The antipassive is indicated by the antipassive morpheme $-i s y^{2}$-. Unlike the passive which is a prefix, the antipassive morpheme is a suffix as shown below:

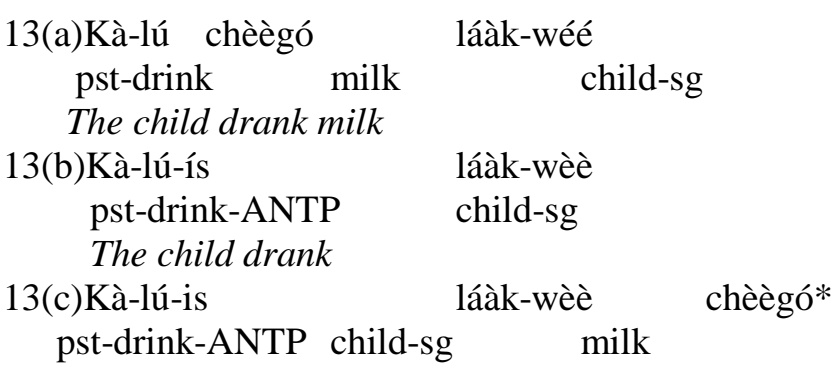

From the above, we can see that in 13(a) the subject laakwee 'child' bears the nominative case of HL tone while object bears absolutive case with LH tone. In 13(b) the construction only contains the subject. The object is left implicit. The verb also has the suffix -is. This suffix turns the transitive construction to be intransitive. The implicit object is also interpreted as 'something'. It is non specific. As can be seen in 13(c), the presence of the object renders the sentence ungrammatical. In the above example, the sentence structure has both the agreement subject and agreement subject heads in 13(a) to check for the subject and object features but in 13(b) the agreement object head is not created instead, the antipassive head is created to check for the antipassive features. The antipassive as a valence reducing operator blocks the syntactic appearance of the logical object. However, the implicit features of the logical object are checked covertly at LF. The features of this logical object block specificity. The antipassive in Tugen can also be seen through agreement. The agreement marker for the third person is null but the $1^{\text {st }}$ and $2^{\text {nd }}$ person have agreement markers both in the singular and plural. The antipassive can be used in the $1^{\text {st }}$ and the $2^{\text {nd }}$ person as seen below:

14(a)Kì̀-á-chám láák-wéé child-sg ànéé
pst-1-like I
I liked the child
14(b)Kì̀-á-chám-ísy-è
pst-1-like-ANTP-FV
I liked
14(c)Kòò-ó-sóóm pèèk òkwéék
pst-2pl-borrow water you.
You asked for water
14(d)Kòò-ó-sóóm-s-è
pst-2pl-borrow-ANTP-FV ó-kwéék
You asked. you

${ }^{2}$ Its allomorphs are $\{\mathrm{s}\}$ and $\{$ is $\}$

194 
In the examples above, the pronominal subject prefix corresponds with the initial vowel of the lexical pronoun in 14(a) and 14(c). The presence of the antipassive in 14(b) and 14(d) does not affect the appearance the pronominal agreement marker on the verb. The use of the pronominal marker and the lexical pronoun shows a marked construction. This is usually for emphatic reasons.

\subsection{Antipassive and related constructions}

In various languages, the antipassive has been seen to have a correlation with the imperfective/irrealis. In Tugen, the antipassive not only occurs with the imperfective and perfective but also can occur with different tenses as seen below:

\begin{tabular}{cl} 
15(a)ám-ísy-éí & láàk-wèè \\
eat-ANTP-IMP & child-sg \\
The child is eating & \\
15(b)Kì̀-kā-ám-ís & \multicolumn{1}{c}{ láàk-wèè } \\
pst-PER-eat-ANTP & \multicolumn{1}{c}{ child-sg } \\
The child had eaten & \\
15(c)Kà-ám-ísy-èí & láàk-wèè \\
pst-eat-ANTP-IMP & child-sg \\
The child was eating & \\
15(d)Kà-kō-ám-ís & láàk-wèè \\
pst-PER-eat-ANTP & child-sg \\
The child has eaten &
\end{tabular}

From the examples, we can see that the use of the antipassive does not occur only with the imperfective but also with the perfective. This implies that the event cannot only be interpreted as incomplete or continuous.

The antipassive has also been argued to have syncretism with other detransitivising affixes e.g. the reflexive/reciprocal, the passive, anticausative and the middle, Polinsky (in press). In Tugen, this syncretism is only seen with the middle. The middle shows an event that affects an object without reference to the agent. In Tugen the middle bears a modal in addition to the antipassive suffix ${ }^{3}$. The middle in Tugen does not have to be modified by an adverb. Furthermore, the middle appears only in the imperfective as shown below:

\begin{tabular}{|c|c|c|}
\hline $\begin{array}{l}\text { 16(a)Tíl-éí } \\
\text { cut-IMP }\end{array}$ & & $\begin{array}{l}\text { Kíp-túúm } \\
\text { M-John }\end{array}$ \\
\hline \multicolumn{3}{|l|}{ John is cutting a tree } \\
\hline $\begin{array}{l}\text { 16(b)Tíl-àk-s-èì } \\
\text { cut-M-ANTP-IMP } \\
\text { The tree cuts }\end{array}$ & $\begin{array}{l}\text { kèèt-ít } \\
\text { tree-sg }\end{array}$ & \\
\hline $\begin{array}{l}\text { 16(c) Yáát-àk-s-éí } \\
\text { open-M-ANT-IMP } \\
\text { The door opens now }\end{array}$ & $\begin{array}{l}\text { kùrg-éé } \\
\text { door-sg }\end{array}$ & $\begin{array}{l}\text { ngúnóó } \\
\text { now }\end{array}$ \\
\hline
\end{tabular}

As can be seen above, in Tugen it is not obligatory for the middle to include an adverb.

The antipassive has also been argued to be related to ergativity. Cooreman (1994:50) says that the antipassive is a construction typical for ergative languages and occurs with ergative constructions as a morphological alternative for the same transitive proposition. Polinsky (in press) on the other hand, refutes this observation by saying that in ergative languages the antipassive is associated with the change of case, hence it is more noticeable. We concur with Polinsky's observation because in Tugen the presence of the antipassive does not change case alignment. It retains the marked nominative as can be seen in 12(b). It therefore does not have any relationship with ergativity in Tugen.

\footnotetext{
${ }^{3}$ The antipassive suffix is /s/ because the modal ends with a consonant.
} 


\subsection{Antipassive and valence operations}

The antipassive is a valence reducing operation. It removes the logical object from the sentence structure. In Tugen, the antipassive can occur with valence reducing as well as the valence increasing operations. The valence increasing operations in Tugen involve the applicative i.e. the benefactive, the locative and the instrumental. This is exemplified below:

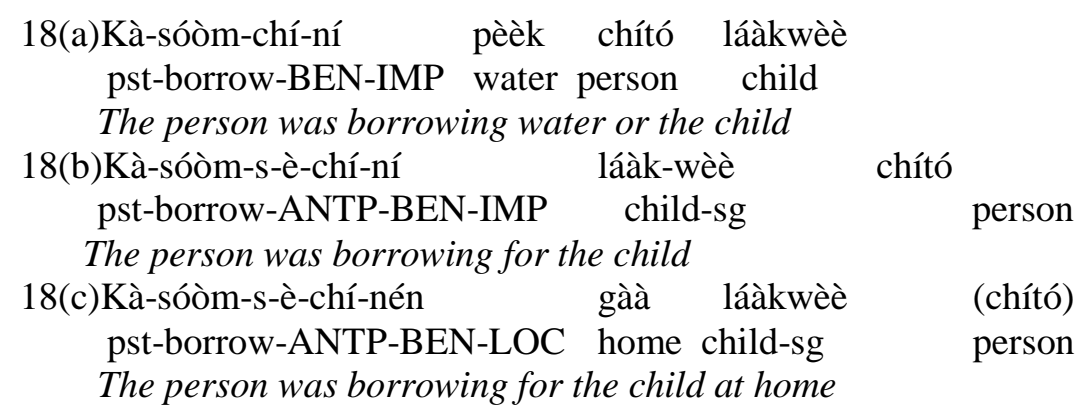

In 18(a), the benefactive increases the valence of the verb by introducing the benefactive argument laakwee 'child'. The presence of the antipassive in 18(b) and 18(c) reduces the direct object argument and therefore reduces the valence of the verb by one argument. The presence, however, of many derivational affixes renders the sentence clumsy when all the arguments appear. In most cases such a construction like 18(c) is used in discourse when background information is available about the subject or the benefactive argument. Besides the antipassive, other valence reducing operations in Tugen include the reflexive/reciprocal and the passive. The antipassive in Tugen can only co co-occur with passive as seen below:

19(a)Kì̀-ám píí kìmnyéé
pst-eat person-pl food
People ate food
19(b)Kì̀-kí-ám kìmnyéé
pst-PASS-eat food
Food was eaten
19(c)Kì̀-kí-ám-ís
pst-PASS-eat-ANTP
Eating was done ('People' ate)

As can be seen from 19(c), when the passive and the antipassive co-occur, the construction remains argumentless syntactically. The antipassive and the antipassive can also co-occur with the applicative and the reflexive/reciprocal in Tugen. This can be seen below:

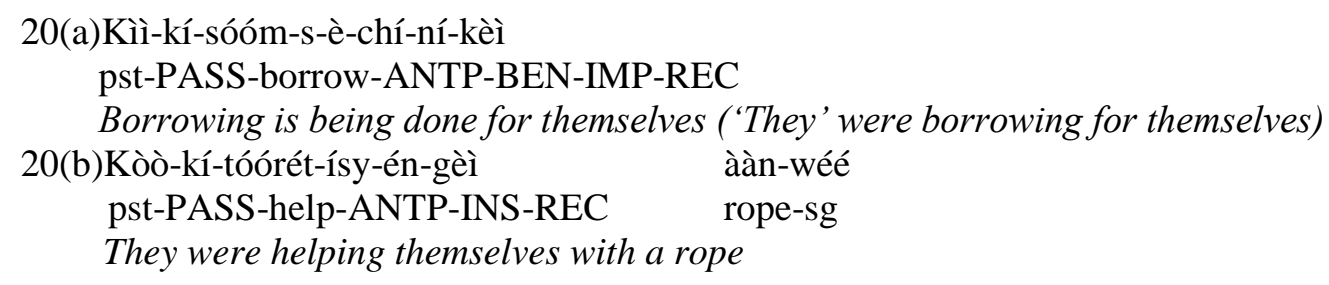

In the example above, the use of the passive and the antipassive together with the reciprocal renders the construction argumentless. The passive reduces the subject. This subject is co-referential with the benefactive argument and the reciprocal. The antipassive reduces object. This is similar with 20(b) though in this construction the affix -en introduces the instrumental argument. Such constructions are used in discourse where the information on the referents is already available. A construction such as 20 (b) is used when the argument is being introduced into discourse. 


\subsection{Function of the passive and the antipassive}

In Tugen, the passive is used to defocus the agent (Shibatani 1985). The antipassive is used when one wants to focus on the activity and the agent while defocusing the object . The defocusing of the agent in the passive is done by the use of the third person plural indefinite pronoun. The defocusing of the object in the antipassive is done by demotion syntactically.

\subsection{Conclusion.}

Passive and the antipassive in Tugen are both detransitivizing constructions syntactically. The constructions remain semantically transitive. Both these constructions are reflected in the verb by affixes; the passive is a prefix while the antipasive is a suffix. Both of these affixes bear $\mathrm{H}$ tones. The passive subject is interpreted as third person plural and therefore Tugen does not have a true semantic passive. The internal argument is not promoted and shows ergative case marking. The passive is differentiated from the unaccusatives lexically. The antipassive on the other hand lacks a structural object. However there is an implicit one that is non specific. In constructions, the passive blocks the agreement feature from projecting the subject syntactically while the antipassive blocks the object from being projected syntactically. However, both the arguments are present logically and can be interpreted as nonspecific or general. The antipassive does not have a relation with ergativity in Tugen. The sole argument in an antipassive construction retains nominative case. The antipassive also shows syncretism with the middle. Both the passive and antipassive are valence-reducing operations. They can co-occur with valenceincreasing operations and they both can co-occur in a construction. The antipassive and the passive in Tugen are used to focus on the action, while being vague on respective arguments.

\section{References}

Abraham, W. (2006). 'Introduction: -Passive and Typology' In Abraham W. \& Laura L. (eds) Passivization and Typology-Form Vs Function Amsterdam/Philadelphia; John Benjamins Publishing Company.

Alexiadou, A \&Schafer F (2013). 'Non-canonical Passives' In Alexiadou A\& F. Schafer (eds) Non Canonical Passives. Amsterdam: John Benjamins.

Alridge E. (2012). Antipassive and Ergativity in Tagalog. In Lingua 122:192-203.

Baker, M. (1988). Incorporation: A Theory of Grammatical-Function Changing.Chicago: University of Chicago Press.

Blevins J. (2003). 'Passives and Impersonals' Journal of Linguistics 39: 473-520.

Chomsky, N. (1995). The Minimalist Program. Current Studies in Linguistics 28. Cambridge/Mass: MIT Press.

Chomsky, N (1981). Lectures on Government and Binding. Dordrecht:Foris Publications.

Cooreman A. (1994). 'A Functional Typology of Antipassive Voice' In Barbara F. \&Paul H (eds) Voice: Form \& Function, 49-88. Amsterdam; John Benjamins.

Dixon, R. M. W. (1994). Ergativity. Cambridge: Cambridge University Press.

Dixon, R.M.W \&Aikhenvald A.Y(2000). Changing Valency: Case Studies in Transitivity. Cambridge: Cambridge University Press.

Jerono, P. A. Chelimo, E. Chebet \& J. Chepkirui (2014). "Passive in Southern Nilotic" In BEST: International Journal of Humanities, Arts, Medicine and Sciences, Vol 2. Issue 6 pp 27-36.

Jerono, P. (2012). Tugen Word Order-A Minimalist Perspective. Macedonia: EGALITE

Marantz, A. P.(1984). On the Nature of Grammatical Relations. Cambridge/Mass: MIT Press

Schröder, H. (2015). "Alignment Systems and Passive-Antipassive Distribution in Nilotic Languages" In University of Nairobi Journal of Linguistics and Languages, Vol. 4 pp 42-81.

Schröder, H. (2008). Word Order in Toposa: An Aspect of Multiple Feature Checking. SIL International and University of Texas at Arlington.

Shibatani, M. (1985). 'Passives and Related Constructions: a Prototype Analysis' Language Vol 61 (4) 821-848.

Siewierska, A. (2010). "From 3pl to passive, Incipient, Emergent and Established Passives " In Diachronica: International Journal for Historical Linguistics, 27/1 pp 73-109.

Polinsky, M. (to appear) 'Antipassive' In Handbook of Ergativity. www.scholar.harvard .edu/files/mpolin ksy/files/antipassive_new.pdf.

Polinsky, M. (2013). “Antipassive Constructions" In: Dryer M.S\& Haspelmath, M(eds) The world Atlas of language structures Online. Leipzig; Max Planck Institute.www//wals.info/chapter/108..accessed on 2015-06-22. 